\title{
Developing an Instructional Model Assisted Audio Visual Media
}

\author{
Novelti, Syahrul, R., Ermanto, Agustina \\ Universitas Muhammadiyah Sumatera Barat \\ Universitas Negeri Padang \\ noveltiumsb@gmail.com
}

\begin{abstract}
Bahasa Indonesia teachers should be able to create an atmosphere of learning that can motivate participants who are in the middle of adolescence (12-14 years). Teachers can use an interesting media to help learners in uttering ideas. This study done to (1) analyze the developing an instructional model assisted audio visual media of descriptive in Bahasa Indonesia lesson of junior high school; and (2) examine the validity, feasibility and effectiveness of an instructional model assisted audio visual media of descriptive in Bahasa Indonesia Lesson of junior high school. This research was development research. This research used to produce an instructional model assisted audio visual media of descriptive in Bahasa Indonesia lesson of junior high school and simultaneously test the validity, feasibility, and effectiveness. This research used 4-D development model which consists of (1) define; (2) design; (3) develop; and (4) disseminate. This research revealed an instructional model assisted audio visual media of descriptive in Bahasa Indonesia lesson of junior high school in the form of model book, teacher manual, student manual, and audio visual media video had been valid from linguistic aspects, content and learning materials, literary, display and presentation; practical based on the questionnaire results for students and teachers and the results of observation of learning implementation; and effective seen from the observation of students' activities during learning using the model.
\end{abstract}

Keywords--Instructional Model; Descriptive Text; Audio Visual Media; Learning Bahasa Indonesia

\section{INTRODUCTION}

Language has a central role in the intellectual, social, and emotional development of learners. Language is the support of success in learning. Language learning is expected to help learners know himself, his culture, and others. In addition, language is used to express ideas and feelings, participate in society, discover and use their own analytical and imaginative abilities (MoNE, 2007).

In practice, Learning Bahasa Indonesia focuses on four aspects of skills which need teachers' creativity to achieve good learning outcomes. The four aspects of the skill are also required to study other subjects. Each aspect of Bahasa Indonesia skills are interrelated from one another. For example, one can speak because he is capable of listening, or skilled at reading, and writing. Similarly, a skilled person writes, if he is skilled at listening, speaking, and reading. Each skill is related to each other. Language skills are usually obtained through a regular sequence of relationships starting from listening, then speaking afterwards learning to read, and write (Tarigan, 2016). Although in the final sequence, writing is a very important activity because it requires creativity and productivity.

The learning model adapted to the 2013 curriculum, outlines the core competencies are examination, reasoning and presentation related to the development of competencies according to the learning outcomes in schools independently, acting effectively, and able to use the method according to the rules of scientific. Its main competencies are then described in basic competencies which include (1) understanding the structure and rules of literary texts; (2) comparing texts of literary works; (3) analyzing literary texts; (4) evaluating literary texts; (5) to interpret the meaning of literary texts; (6) produces literary texts; (7) edit the literary works; (8) making literary abstract works; and (9) transforming literary works into other forms according to the structure and rules of the text, both oral and written.

Research on the descriptive text and literary texts conducted by several countries among Indonesia by Sari, Kristiawan, \& Syaveny (2015) from West Sumatera. Tiur Asih Siburian (2013) from Medan State University about improving students' achievement on writing descriptive text through 32 think pair Share. Hasan Atmaca \& Günday, R (2016) from Ondokuzmays University of Samsun Turkey, under the title Using Literary Texts to Teach Grammar in Foreign Language Classroom. Furthermore, Eric Gomez Burgos (2015) of Universidad de Los Lagos, Puerto Montt, Chile, entitled First Year University Students Use of Formulaic Sequences in Oral and Written Descriptions, and Lin Jiang, (2015) of the University of Foreign Studies, Guangzhou, China, entitled The Effectiveness of the Continuation Task on Second Language Learning of English Articles. The study concluded not many students have understood the contents of the descriptive text and the literary texts it reads. 
Based on the results of preliminary observations conducted at SMP Negeri Padangpanjang, it was found that the learning activities of Bahasa Indonesia still using conventional methods. Teachers rarely use the multimedia in learning activities, so less spirit of learners. Teachers did not make innovative learning such using a variety of media to make learners motivated in learning process. Likewise with the limitations of the ability of Bahasa Indonesia teachers in using learning media, plus teachers often get in late, and let learners are out of the classroom, this makes learning less meaningful and unsuitable with the goal of learning. Moreover, the demand for KKM was 75, if not achieved it will be held remedial.

In addition, the selection of appropriate learning models, learning media were needed to improve the effectiveness of learning quality. Lyubov, Dmitrievna Ponomareva (2016) argued that in modern context a teacher must use electronic learning media.

Many researches done regarding the use of audio-visual media in learning such as, Beechler, Susan \& Williams, Sherie (2012), entitled Computer Assisted Instruction and Elementary ESL Students in Sight Word Recognition. Kim, D., \& Gilman, DA (2008), from the Department of Mathematics Education at Korea National University of Education, entitled Effects of Text, Audio, and Graphic Aids in Multimedia Instruction for Vocabulary Learning. Furthermore, Kristiawan (2014) from West Sumatera, Mathew, N. G., \& Alidmat, A. O. H. (2013), from Aljouf University, Saudi Arabia, entitled A Study on the Usefulness of Audio-Visual Aids in EFL Classroom: Implications for Effective Instruction. Then, Bello, S., of the Department of Education, University of Maiduguri, under the title Journal of Education and Practice Journal of Education and Practice , (2016). And Shabiralyani Ghazi, et al., From Dera Ghazi Khan University, Punjab Pakistan, under the title Impact of Visual Aids in Enhancing the Learning Process Case Research: District Dera Ghazi Khan. The study concluded that the use of audio visual media can increase students' attention in learning.

Along with the rapid development, the media used should be varied. One of them uses audio visual media that involves various senses in a learning process. The media provide experience directly, can be through computers and the Internet and all sources to communicate. The intended media used hardware, such as computers, televisions, projectors, LCD, and software such as microsoft power point, macro media flash, visual basic, audio visual, and others used on hardware. According to Siddiqui \& Khatoon (2013) findings that computer in learning was more effective in enhancing the students' achievement in Physical Science than traditional instruction. Then Premalatha (2012) also concluded his findings that the computer in learning to provide learners with conducive environment at school and home by motivating them to involve in the study and making learning interesting. In addition, Karami, Karami \& Attaran (2013) also concluded that trainees who may integrate knowledge and teaching skills.

Technological developments changed the paradigm of the public in obtaining information where not only limited to print, radio, and television, but also to global networking technologies and the Internet, as one of the main sources of information. Teachers can obtain various information based teaching materials, such as text, photos, audio visuals, videos, animations, and simulations. Internet technology also makes it easy for students to get additional information in order to meet the demands of competence and also enrichment. The use of technology in learning is expected to encourage the emergence of communication, creativity, and able to solve the problems faced by learners.

Looking at the current developments, it is no longer the time for teachers to teach conventionally by using lecturing and memorizing methods. The paradigm shift in the teacher centered becomes students centered learning. Currently, teachers are not the only source of learning, even teachers must continue to learn in order not miss information from learners.

The learning process should be accompanied by observing activities, questioning, trying, reasoning, presenting, and creating. Observing and questioning activities can be done within the school, or outside the school, so the learning activities not only occur in the classroom, but also in the community. The teacher's role in learning shifted into a learning designer for active learners to gain new knowledge. Innovation of language teaching contributes to the learning process becoming student-oriented, for instance, it allows implementing project activities in accordance with the requirements of modern educational standards. Using this approach, one can get interactive training, which enables to change the role of a teacher who is in the classroom acts as an organizer, expert, tutor, and a facilitator (Dorfman and Javidan, 2016). Creative teachers should be skilled at designing diverse activities, and the learners are fully involved in the learning process. Learners will feel bored if the teaching methods monotonous. On the contrary, learners will be motivated to learn if teachers apply varied methods.

A student-centered learning approach produces learners who are personable, intelligent, active, and independent. Learners are subjects not objects that only receive information from teachers. Learners have larger roles and activities. Technological advances allow everyone to access information more quickly with no time limit.

In the study of descriptive text (which is one of the main subjects in Bahasa Indonesia subjects in junior high), most teachers do not understand the purpose of the learning itself. Learning descriptive text requires teachers to sharpen the 
skills of learners in describing things clearly. So, learners seem to feel directly what is described by describing object, place, or event and put it into the literary text (short story).

Correspondingly, the literary texts at the secondary level are not particularly focused. Complaints and criticisms about the lack of literary content in the curriculum have often been discussed. In fact, language is a medium for the birth of literature. This is in accordance with research conducted by Mustafa (2016) in learning literature should be made in order to successfully address the needs of local communities with character education through literary texts. To address the needs of local people with character education through literary texts, there must be an effort to learn them.

Furthermore, literary texts are specifically considered very worthy juxtaposed with the descriptive text on learning Bahasa Indonesia, because in the literature there is a humanistic aspect. Learning without the balance of artistic values gives a robotic generation, rigid, and indifferent to humanistic values. In other words, the development of descriptive text inserted into the literary and audio-visual media where expected to be more meaningful to the students' knowledge, skills and attitudes in everyday life, both in the school and community. Therefore, teachers should use media or electronic aids in the form of learning video cassettes in the process of achieving good skills. If teachers only provide material conventionally will certainly make learning Bahasa Indonesia becomes boring and not interesting for learners.

\section{METHODS}

This research was Research and Development which used to produce products, and at the same time tested the effectiveness. By using Research and Development, it could find and tested new products useful for the life. The development model used in this research was the 4-D which consisted of 4 main stages (1) define, (2) design, (3) development, and (4) dissemination. After testing the product successfully, the next step was tested in real condition. The trial was to determine the feasibility of the resulting product. The trial of the development of instructional model of audio visual media on Bahasa Indonesia subjects at junior high school level was conducted with broad sample. The broad sample in this research was two SMPN in Padangpanjang, high level school group and low level school group. The grouping of this school was based on information of the Department of Education of Youth and Sports of Padangpanjang in 2017, on the average achievement of National Examination year 2016/2017. Based on the average acquisition of National Examination, rank, class, and school location geographically then taken two SMPN that categorized high level school group was determined SMPN 1 Jalan Jenderal Sudirman No. 41 Kota Padangpanjang and low level school was set at SMPN 3 Jalan A. Yani no. 93 Tail Lubuk Kota Padangpanjang. The product trial was intended to collect data that can be used as a basis for determining the level of achievement of the use of the development of instructional model of audio visual media assisted descriptive text in Bahasa Indonesia subjects in junior high school.

Instruments used in this study were (1) guidelines for observation, to observe students learn the Learning Bahasa Indonesia using descriptive text; (2) questionnaire was used to obtain an overview of the various issues that occur while using descriptive text; (3) RPP quality validation development sheets, literary texts, and audio-visual media by experts. The RPP activities were designed in columns that have been created for the activities of teachers and learners according to the use of descriptive text. Similarly, in the development of literary texts also designed activities that integrated with the learning process and audio visual media to be developed; and (4) interview guide.

This experimental design was done after the development of learning model descriptive text was valid, then tested to the students in class VII of SMP Negeri 1 and SMP Negeri 3 Padangpanjang as users. In this test phase, given treatment in the form of learning. In the testing phase, the following activities were carried out trials were conducted to one local VII classroom student, A local (superior grade) studying at SMP Negeri 1 Padangpanjang and one local VII class student, local G (regular class) studying at SMP Negeri 3 Padangpanjang. The purpose of this trial was to obtain an overview of the development of instructional models of descriptive text. It was done to determine the level of performance expected on the subjects of the Bahasa Indonesia. In other words, when each learner has successfully completed the task in KD 3.1 and KD. 4.1 in good criteria up to $80 \%$, then the product was considered valid.

\section{FINDING AND DISCUSSION}

The data analysis begins from needs analysis. FGD on December 12, 2016 concluded that the media used by teachers only the teacher's books and student's books, there is no descriptive text inserted into short story text. Moreover, there is no short story made into the media. The learning process is still using the tools available in schools. Interview with Ms. SA from SMP Payakumbuh, Ms. Y from SMP Bukittinggi, and Ms. SE from SMP Padangpanjang whom active in the MGMP activities of West Sumatra found the learning is still conventional, the media used were limited, and the teacher less creative in developing the learning model, especially in the learning of the descriptive text. From the results of the initial FGD, illustrates that there is no major innovations or renewals in the development of learning model descriptive text which 
easy to understand and interesting for learners. There are still many Bahasa Indonesia teachers who are unable to teach literature.

Next, the student's analysis includes the students' age, interests, talents, social life, and the tendencies of learning styles and basic skills possessed by junior high school students. In this study, the subject is the students of SMPN Padangpanjang class VII which averaged aged between 12-14 years who are in the middle stage of adolescence. Then, concept analysis done to determine the main concepts of descriptive text material, this concept must be understood by the students in learning descriptive text: KD 4.1. explain the contents of the object descriptive text (attractions, historical places, local art performances, traditional cloths, etc.) that are heard and read orally, written and visual while the competency achievement indicator (1) maps the descriptive text (topics and sections); (2) reports the information contained in the descriptive text that he reads and hears to the written form in accordance with the descriptive characteristics and structure of the text.

Model Analysis explains the research findings related to the teacher's descriptive text model (Master Model). This finding is based on the results of interviews with teachers of Bahasa Indonesia study at SMP Negeri Padangpanjang and observations conducted at the school where the study was conducted. Interviews were conducted with two Bahasa Indonesia teachers at SMP Negeri Padangpanjang on Monday, September 5, 2016. In the interview, the teacher explained about the steps of the learning model with the descriptive text that was implemented 1) in the initial activity, the teacher explained about the related learning materials 2) in the core activity, the teacher asks the students to make a descriptive text, on this material the students work individually or in groups with 5 or 6 members, or come to the front of the class then the discussion depends on the time remaining; 3) on closing activities the teacher provides motivation to the students.

Design phase, at this stage the researchers designed the development of instructional model assisted audio visual media of descriptive text in Bahasa Indonesia lesson of junior high school. The set of tools, the Learning Implementation Plan (RPP) is systematically designed which contains the components of RPP identity, SK, KD, indicators, learning objectives, learning materials, learning methods, learning steps, learning resources, and assessment. The learning scenario for each meeting consists of audio-visual media assisted learning activities and integration the audio-visual media assisted descriptive text.

The model books, which have been designed to be modeled in audio-visual media assisted descriptive text fits with Junior High School students and descriptive text material. The audio visual assisted text is named Development of Audio Visual Media Deciphered Model. The model was developed based on learning descriptive text of Bahasa Indonesia subjects conducted by Bahasa Indonesia teachers at the Junior High School.

Student book is needed to facilitate learners to understand the teaching materials and absorb information in the learning process. The developing student book refers to previously formulated indicators. Presentation of students' books in the form of printed materials, processed using Microsoft Office using the type of Comic sans MS, Caliber, and TW Cen MT size 12 and equipped with drawings and audio visual media, so the learners more spirit in learning descriptive text. Master's book is a learning tool, guidance in providing materials that will be delivered according to what has been prepared in the RPP. The teacher's book is designed as exciting as possible, to make it easier for the teacher to re-explain the material presented to the students. The teacher's book is also organized according to the learning needs of audio visual assisted descriptive text.

According to Thang Siew Ming (2010) this is supported by a Delphi study by Clark (2006) that recommends time to be made available for knowledge and skills to support the uptake of new technologies. This is supported by Delphi's study by Clark (2006) which recommends that time should be available for teachers to work together, share one another and share in order to gain new knowledge and skills to support the uptake of new technologies.

In development phase, validation of design devices followed by validation activities by experts of linguistic Dr. Novia Juita, M.Hum; media and IT validator Dr. Sarjon Defit, S. Com. M.Sc.; the validator of Bahasa Indonesia teaching Prof. Dr. Yasnur Asri, M.Pd., and Dr. Abdurahman, M.Pd.; and a literary validator was Yeni Hayati, M. Hum. Validation results and suggestions of improvements provided by validators are used to revise model books, teacher manuals, student manuals, and audio-visual media. Validation of model books, teacher and student manuals, and media that have been developed, are then validated by validators who have been advised by mentors on the basis of their respective expertise. Prior to validation, all products that have been made have been revised several times in accordance with FGD results, trials, and validator suggestions. The result of Interclass Correlation obtained from SPPS shows that the overall rating is very good 0.727, but when using one rater value of Interclass Correlation to 0.182 weak category. From the result of the whole validity indicates that the developed product has been valid

Book validation of the descriptive text model is conducted through discussions with experts conducted in Padang in November 2017. The discussion is divided into three sections, the model validation consists of 5 experts linguistic validator are Novia Juita, M.Hum., Media and IT validator; Dr. Sarjon Defit, S. Com., M.Sc., the validator of teaching 
Bahasa Indonesia; Prof. Dr. Yasnur Asri, M.Pd., and Dr. Ir. Abdurahman, M.Pd., and Yeni Hayati, M. Hum a literary validator. The result of validation of learning model is done by expert obtained on average, 3,88 with percentage $77.6 \%$ including good category. This means that the development of instructional model of audio-visual assisted descriptive text included in both categories seen from the aspect of conformity of objectives, media attractiveness, material suitability, and material completeness, completeness of evaluation, feedback and accuracy of language use of five experts stated text learning model audio visual assisted descriptive text.

Book validation of teachers on learning audio visual media assisted descriptive text validated by 5 experts according to their respective of validation learning, language, content, display and audio visual aspects used in designing instructional model of media-aided descriptive text audio visual. The results of validation of the learning model by the experts obtained an average value, 3.70 with a percentage $92.5 \%$ including very valid category. This means that the instructional model of audio-visual descriptive text included in the valid category, viewed from the aspects of learning and language, content aspects, display aspects, and audio visuals are assessed by five experts.

Student book validation assessed by validator in general is 3.23 with a very valid category. From the assessment aspect the average value of the material as a whole is 3.23 , linguistic aspect 2.75 and visual audio display aspect 2.67 with a valid category. The student's book who have developed well, certainly can be used as a source of learning for students in the process of learning audio visual assisted media. Student books are structured to ease understanding and improve memory of instructional text materials. The value of Interclass Correlation results indicate that the overall rater good judgment 0.918 . However when using one rater the value of Interclass Correlation becomes 0372 is enough category.

The learning outcomes of cognitive aspect to know the effectiveness of instructional model of audio-visual assisted descriptive text from done from formative test. Problems are given after the instructional model of audio visual assisted descriptive text was tested. In analyzing the learning outcomes in the cognitive aspects of learners, used learning completeness criteria. Completeness learners seen from the learners' learning outcomes through formative tests were compared from the KKM. The results of learning has been achieved, it appears that learning descriptive text audio visual assisted media can help learners in understanding the material to obtain good results. This can be seen from the average score obtained by the learners 83.62 above the KKM 73 for SMPN 3 Padangpanjang and the average learning outcomes for students SMPN 1 Padangpadang, 90.2 above the KKM 78.

Learning outcomes on the affective aspects obtained from the observer's observation of student characteristics during the learning took place. Observation of affective aspect was done by two observers at SMPN 1 Padangpanjang and SMPN 3 Padangpanjang. The score of the affective achievement in SMP N 1 and SMPN 3 Padangpanjang is in good category. This shows that the instructional model of audio-visual assisted descriptive text can improve learning outcomes on the affective aspect. Psychomotor aspect learning outcomes are taken from the observer's observation on the learners' performance during the learning process. Assessment of students is done individually in the group where the average score of psychomotor students SMPN 1 and SMPN 3 Padangpanjang is 82.52 with good category. The acquisition of the average score of learners in each model of audio-visual assisted text learning shows the same average score between a superior class and an ordinary class.

Learning scenarios prepared can lead learners to have cognitive, affective, and psychomotor knowledge. According to Adiyanto (Zubaedi, 2011) the purpose of learning Bahasa Indonesia is to include the development of the cognitive (knowledge), psychomotor (skills), and affective (attitude and values). In the learning process, learners play an active role, creative, critical, and gain direct experience so that learning becomes more meaningful. The result of the validation of instructional text book with audio visual descriptive text shows very valid category with the average score of validation 3,88 . The model book is declared valid by the validator indicating that the developed model book has been according to the instructional descriptive text material. Thus, it can be said that the validity of the contents of the model book can be accounted because it has been assessed and valid by experts.

\section{CONCLUSION}

This research was development research. This research used to produce an instructional model assisted audio visual media of descriptive in Bahasa Indonesia lesson of junior high school and simultaneously test the validity, feasibility, and effectiveness. This research used 4-D development model. This research revealed an instructional model assisted audio visual media of descriptive in Bahasa Indonesia lesson of junior high school in the form of model book, teacher manual, student manual, and audio visual media video had been valid from linguistic aspects, content and learning materials, literary, display and presentation; practical based on the questionnaire results for students and teachers and the results of observation ofs learning implementation; and effective seen from the observation of students' activities during learning using the model. 


\section{References}

Atmaca, H., \& Günday, R. (2016). Using Literary Texts to Teach Grammar in Classroom Foreign Language. Participatory Educational Research (PER), (2016.IV), 127-133. Retrieved from http://www.partedres.com/archieve/spi_16_4 / per_16_spi_4_17.pdf

Burgos, E. G. (2015). First Year University Students Use of formulaic sequences in oral and written descriptions. Journal Profile, 17 No. January 1-June 2015 ISSN 1657-0790 (printed) 2256-5760 (online) Bogota, Colombia

Beechler, S. \& Williams, S. (2012). Computer assisted instruction and elementary ESL students in sight word recognition. International Journal of Business and Social Science 3 (4) Special Issue - February 2012.

Bello, S. (2016). Relationship between audio-visual materials and environmental factors on students academic performance in senior secondary schools in bureau states: Implications for Counseling, 7 (24), 173-177

Clark, D. (2006). Games and e-learning. Caspian Learning Engaging Minds Ltd. Caspian Learning Ltd. St. Peters Gate. Charles Street. Sunderland SR6 0AN www.caspianlearning.co.ukinfo@caspianlearning.co.uk.

Depdiknas. (2007). Language learning instructional guidelines at Kindergarten. Jakarta: Depdiknas

Dorfman, P. W., and Javidan, M., (2016). CEO of intellectual stimulation and employee work. meaningfulness: The moderating role of organizational context.group \& organization management 2016, 41 (2) 203-231

Jiang, L. (2015). The Effectiveness of the Continuation Task on Second Language Learning of English Articles. English Language Teaching, 8 (11), 79. https://doi.org/10.5539/elt.v8n11p79

Karami, M. Karami, Z. \& Attaran, M. (2013). Integrating problem-based learning with ICT for developing trainees teachers' content knowledge and teaching skills. International Journal of Education and Development using Information and Communication Technology (IJEDICT), 2013, 9 (1), pp. 36-49.

Kim, D., \& Gilman, D. A. (2008). Effects of text, audio, and graphic aids in multimedia instruction for vocabulary learning. Educational Technology and Society, 11 (3), 114-126. https://doi.org/10.1111/j.1467-8535.2010.01145.x

Kristiawan, M. (2014). A Model for Upgrading Teachers Competence on Operating Computer as Assistant of Instruction. Global Journal of Human-Social Science Research.

Liang, J. \& Tsai, C. (2008). Internet self-efficacy and preferences toward constructivist internet-based learning environments: A Study of Pre-School Teachers in Taiwan. Educational Technology \& Society, 11 (1), 226-237

Lyubov, D. P, et al. (2016). Russian national corpus as a tool of linguo-didactic innovation in teaching languages. Journal of educational and pranctise 11 (18), 13043-13053

Mathew, N. G., \& Alidmat, A. O. H. (2013). A study on the usefulness of audio-visual aids in EFL Classroom: Implications for Effective Instruction. International Journal of Higher Education, 2 (2), 86-92. https://doi.org/10.5430/ijhe.v2n2p86

Mustafa. (2016) .The development of appreciation learning modelof indonesia literature based critical discourse analysis toimprove the students' critical thinking skill. Journal of Educational And Practice 7 (33), 2016ISSN 2222-1735 (paper), ISSN 2222-288X (online).

Ming, T. S., Hall, C., Azman, H. \& Joyes, G. (2010). Supporting smart school teachers' continuing professional development in and through ICT: A model for change. International Journal of Education and Development using Information and Communication Technology (IJEDICT), 2010, 6 (2), pp. 5-20.

Premalatha, U.M. (2012). An empirical study on the attitude of high school students towards computer-assisted instruction with respect to their study practices. The IUP Journal of Soft Skills, 4, (2), pp. 34-44, June 2012.

Sari, H. P., Kristiawan, M., \& Syaveny, N. (2015). The Effect of Think Pair ShareTechnique on Students' Reading Comprehension of Hortatory Exposition Text at Grade XI High School 1 VII Koto Sungai Sarik, Padang Pariaman, West Sumatera.

Siburian, T A. (2013). Improving students' achievement on writing descriptive text through 32 think pair share. The International Journal of Language Learning and Applied Linguistics Works (IJLLW) 3 (3), July 2013 ESSN 22892737 ISSN 2289-3245.

Siddiqui, U. \& Khatoon T., (2013). Teaching physical science: Should we implement teacher-centered CAI or StudentCentered CAI at Secondary School Level in India? European Scientific Journal, 9, (10). ISSN: 1857 - 7881

Shabiralyani, G., Hasan, K. S., Hamad, N., \& Iqbal, N. (2015). Impact of Visual Aids in Enhancing the Learning Process Case Research: District Dera Ghazi Khan. Journal of Education and Practice, 6 (19), 226-233.

Tarigan, Dj. \& Tarigan H.G. (2016). Language teaching techniques. Bandung: Space.

Zubaedi. (2011). Character education design. Jakarta: Kencana Press. 